\title{
PERLINDUNGAN PARA PIHAK DALAM PERDAGANGAN SECARA ELEKTRONIK
}

\author{
Tri Ciar Atsetya, Budi Santoso, Adya Paramita Prabandari \\ Program Studi Magiter Kenotariatan \\ FakultasHukum, Universitas Diponegoro \\ Email : ciaratsetya21@gmail.com
}

\begin{abstract}
This study intends to analyze the terms of contract conditions in electronic commerce (ECommerce) type of B2C (Business-to-Consumer or company-with-consumers) that really determine the level of protection for consumers. The main focus is on 3 (three) things, namely: regarding the level of fairness, weaknesses in the information on contract terms as a signal of imbalance position between business actors and consumers, as well as efforts to reconstruct fair consumer protection. Based on the focus of the study, this research is socio-legal research (socio-legal research). The results of this study are the provisions in the ITE Law and the Consumer Protection Act are still very simplistic (simple) to say there is a guarantee of justice in electronic commerce, especially for consumers. Even the ITE Law has not yet regulated the validity of contracts as part of contract conditions information. To this extent justice is still not fully distributed to consumers in electronic commerce. Weaknesses in consumer protection which indicate an imbalance in position between business actors and consumers, namely the ITE Law and the Consumer Protection Law and information on contract conditions allows for unbalanced standard contracts; information on contract conditions is difficult to access; and information on contract terms is incomplete and unclear.
\end{abstract}

Keywords : information; contract terms; consumer

\begin{abstract}
Abstrak
Penelitian ini bermaksud menganalisis mengenai informasi syarat kontrak dalam perdagangan secara elektronik (E-Commerce) jenis B2C (Business-to-Consumer atau perusahaan-dengankonsumen) yang sangat menentukan tingkatan perlindungan pada konsumen. Fokus utamanya pada 3 (tiga) hal, yaitu : mengenai tingkatan keadilannya, kelemahan informasi syarat kontrak sebagai sinyal ketidakseimbangan posisi antara pelaku usaha dan konsumen, serta upaya merekonstruksi perlindungan konsumen yang adil. Berdasarkan fokus studi tersebut, penelitian ini merupakan penelitian sosio-legal (socio-legal research).Hasildaripenelitian ini adalah ketentuan-ketentuan dalam UU ITE maupun UU Perlindungan Konsumen masih sangat simplistis (sederhana) untuk mengatakan telah adanya jaminan keadilan dalam perdagangan secara elektronik khususnya bagi konsumen.Bahkan UU ITE belum mengatur mengenai validitas kontrak sebagai bagian dari informasi syarat kontrak. Sampai pada batas ini keadilan masih belum sepenuhnya terdistribusi pada konsumen dalam perdagangan secara elektronik. Kelemahan perlindungan konsumen yang menunjukkan ketidakseimbangan posisi antara pelaku usaha dan konsumenyaitu UU ITE maupun UU Perlindungan Konsumen dan informasi syarat kontrak memungkinkan pada kontrak baku yang tidak seimbang; informasi syarat kontrak sulit diakses; serta informasi syarat kontrak tidak lengkap dan jelas.
\end{abstract}

Kata kunci : informasi; syarat kontrak; konsumen 


\section{A. Pendahuluan}

Secara hukum, di Indonesia dilakukan pengaturan melalui Undang-undang Nomor 11 Tahun 2008 tentang Informasi dan Transaksi Elektronik, yang diubah oleh Undang-undang Nomor 19 Tahun 2016 tentang Perubahan atas Undang-undang Nomor 11 Tahun 2016 tentang Informasi dan Transaksi Elektronik (selanjutnya disebut UU ITE). Undang-undang Nomor 8 Tahun 1999 tentang Perlindungan Konsumen(selanjutnya disebut UU PerlindunganKonsumen). UU PerlindunganKonsumentersebut dibentuk konteksnyalepasdari perdagangan secaraelektronik. Meskipun demikian niscaya diperlukan untuk melindungi konsumen dalam perdagangansecara elektronik. UU PerlindunganKonsumen hanya mengatur sebatas hubungan antara pelaku usaha dan konsumen. Dalam perdagangan elektronik, hubungan pelaku usaha dan konsumen dapat diperantarai oleh pihak ketiga yang justru menentukan hubungan antara pelaku usaha dan konsumen dapat berlangsung atau tidak, bukan pelaku usaha dan konsumen itu sendiri yang menentukan. Dalam perkembangannya, banyak pelaku usaha yang menghilangkan peran pihak ketiga itu dan menciptakan sistem informasi sendiri. Terlepas dari hal tersebut, studi ini memfokuskan pada persoalan syarat kontrak (terms of contract), yang menghubungkan antara pelaku usaha maupun konsumen untuk masuk ke dalam transaksi perdagangan secara elektronik itu.

Berbeda dengan UU PerlindunganKonsumen, UU ITE dibentuk dalam konteks pertumbuhan dan perkembangan perdagangan elektronik. Meskipun demikian, UU ITE tidak hanya berhubungan dengan perdagangan elektronik, namun mengatur ihwal lebih luas, yang disebut dengan istilah "informasi elektronik" di samping "transaksi elektronik". Dikatakan mengatur ihwal lebih luas dari sekadar perdagangan elektronik disebabkan transaksi elektronik meliputi semua bentuk perbuatan hukum termasuk transaksi di luar perdagangan.(Shidarta, 2000)

Salah satu aspek penting dalam perdagangan secara elektronik yang dapat menjadi indikator perlindungan konsumen dan kejujuran pelaku usaha adalah kontrak elektronik. Kontrak elektronik diartikan sebagai perjanjian para pihak yang dibuat melalui Sistem Elektronik. Arti penting kontrak elektronik bagi perdagangan secara elektronik tampak dari ketentuan UU ITE yang menegaskan bahwa "Pelaku usaha yang menawarkan produk melalui Sistem Elektronik harus menyediakan informasi yang lengkap dan benar berkaitan dengan syarat kontrak, produsen, dan produk yang ditawarkan." Ketentuan tersebut mengatur mengenai syarat kontrak yang lengkap dan benar. Permasalahan muncul tentu berkaitan 
dengan standar informasi yang lengkap dan benar mengenai syarat kontrak (terms of contract). Penjelasan Pasal 9 UU ITE menentukan bahwa :

Yang dimaksud dengan "informasi yang lengkap dan benar" meliputi :

a. informasi yang memuat identitas serta status subjek hukum dan kompetensinya, baik sebagai produsen, pemasok, penyelenggara maupun perantara;

b. informasi lain yang menjelaskan hal tertentu yang menjadi syarat sahnya perjanjian serta menjelaskan barang dan/atau jasa yang ditawarkan, seperti nama, alamat, dan deskripsi barang/jasa.

Pasal tersebut sejalan dengan ketentuan Undang-undang Perlindungan Konsumen Pasal 7 huruf byang menentukan bahwa "kewajiban pelaku usaha memberikan informasi yang benar, jelas, dan jujur mengenai kondisi dan jaminan barang dan/atau jasa serta memberi penjelasan penggunaan, perbaikan, dan pemeliharaan."

Permasalahan syarat kontrak sebenarnya lebih dari sekadar informasi yang lengkap dan benar, namun keseimbangan antara pelaku usaha dan konsumen. Hal ini dapat digantikan dengan ukuran keadilan antara pelaku usaha dan konsumen.(Badrulzaman, 1986)

Ketentuan Pasal 9 UU ITE maupun Pasal 7 huruf b UU Perlindungan Konsumen membutuhkan konsekuensi hukum apabila tidak dipatuhi oleh pelaku usaha, sehingga kerugian konsumen dapat dicegah atau diganti. Hal itu tidak diatur dalam UU ITE, kecuali upaya prevensi dengan adanya "sertifikasi keandalan" yang akan diberikan oleh Lembaga Sertifikasi Keandalan.

Sertifikasi keandalan memang menjadi tanda dapat dipercayanya pelaku usaha perdagangan secara elektronik tersebut, namun sama sekali tidak menafikan (menghilangkan) praktik perdagangan secara elektronik tanpa memiliki sertifikasi keandalan. Artinya, informasi yang lengkap dan benar berkaitan dengan syarat kontrak di bawah standar trust mark (merek terpercaya) mewarnai perdagangan secara elektronik. Hal ini tetap potensial menjadi sumber perilaku pelaku usaha perdagangan secara elektronik yang merugikan konsumen (Blythe, 2012).

Pandangan Aristoteles tentang keadilan bisa didapatkan dalam karyanya nichomachean ethics, politics, dan rethoric. Spesifik dilihat dalam buku nicomachean ethics, buku itu sepenuhnya ditujukan bagi keadilan, yang, berdasarkan filsafat hukum Aristoteles, mesti 
dianggap sebagai inti dari filsafat hukumnya, "karena hukum hanya bisa ditetapkan dalam kaitannya dengan keadilan" (Apeldoorn, 1996).

Pada pokoknya pandangan keadilan ini sebagai suatu pemberian hak persamaan tapi bukan persamarataan. Aristoteles membedakan hak persamaanya sesuai dengan hak proposional. Kesamaan hak dipandangan manusia sebagai suatu unit atau wadah yang sama. Inilah yang dapat dipahami bahwa semua orang atau setiap warga negara dihadapan hukum sama. Kesamaan proposional memberi tiap orang apa yang menjadi haknya sesuai dengan kemampuan dan prestasi yang telah dilakukanya.

Teori keadilan yang memiliki arti persamaan terhadap pemenuhan hak kesehatan seperti teori keadilan Aristoteles yaitu teori keadilan oleh John Rawls. John Rawls dipandang sebagai perspektif "liberal-egalitarian of social justice", berpendapat bahwa keadilan adalah kebajikan utama dari hadirnya institusi-institusi sosial (social institutions). Kebajikan bagi seluruh masyarakat tidak dapat mengesampingkan atau menggugat rasa keadilan dari setiap orang yang telah memperoleh rasa keadilan, khususnya masyarakat lemah pencari keadilan (Faiz, 2009).

Berdasarkan latar belakang di atas, maka rumusan masalah dalam ini sebagai berikut: 1) Mengapa perlindungan konsumen berkaitan dengan informasi syarat kontrak dalam praktik perdagangan secara elektronik belum berbasis nilai keadilan, 2) Apa saja kelemahankelemahan dalam perlindungan konsumen berkaitan dengan informasi syarat kontrak dalam perdagangan secara elektronik.

Fakta menunjukkan bahwa belum banyak hasil penelitian yang berkaitan dengan obyek penelitian baik dalam bentukjurnal. Namun khusus untuk penelitian hukum, dengan keterbatasan kemampuan penulis untuk menelusuri hasil-hasil penelitian di bidang hukum, ada beberapa penelitian tentang penerapan doktrin persamaan pada "Perlindungan Konsumen Dalam Perdagangan Secara Elektronik Berkaitan Dengan Informasi Syarat Kontrak”.

Berdasarkan hasil penelusuran, penulis mendapat penelitian dalam bentuk jurnal yang ditulis oleh Desy Ary Setyawati di tahun 2017 dengan judul "Perlindungan Bagi Hak Konsumen dan Tanggung Jawab Pelaku Usaha dalam Perjanjian Transaksi Elektronik”, yang mengungkapkan dua pokok permasalahan, yaitu: pertama,bagaimana bentuk perlindungan hokum bagi hak konsumen. Kedua, tanggung jawab pelaku usaha dalam perjanjian transaksi elektronik (Setyawati, 2017). 
Jurnal yang ditulis oleh Setia Putra pada tahun 2014 dengan judul "Perlindungan Hukum Terhadap Konsumen Dalam Transaksi Jual-beli Melalui E-commerce" yang mengungkapkan permasalahan yaitu:pertama, bagaimana tanggung jawab para pihak dalam transaksi jual-beli e-commerce. Kedua, bagaimanau paya hokum bagi konsumen yang dirugikan dalam transaksi jual-beli e-commerce (Putra, 2014).

Jurnal yang ditulis oleh Hartini Gunawan pada tahun 2015 dengan judul "Tanggung Jawab Dan Perlindungan Hukum Para Pihak Dalam Transaksi Bisnis Elektronik” yang mengungkapkan dua permasalahan yaitu : pertama, bagaimanakah Tanggung Jawab dan Perlindungan Hukum Para Pihak Dalam Transaksi Bisnis Elektronik. Kedua, pasakahPermasalahanHukum Yang Dihadapi Konsumen Dalam Melakukan Transaksi Bisnis Elektronik (Gunawan, 2015).

\section{B. Metode Penelitian}

Metode pendekatan yang dipilih dalam studi ini adalah metode pendekatan sociolegal (socio-legal study). Suatu studi yang meninjau hukum sebagai fakta sosial yang bisa tersimak di dalam pengalaman sebagai pola perilaku dalam wujud pranata sosial atau institusi sosial, kajian hukum yang mengkonsepkan dan menteorikan hukum sebagai fakta sosial yang positif dan empiris (Wignjosoebroto, 2002).

\section{Hasil Dan Pembahasan}

\section{Perlindungan Konsumen Berkait dengan Informasi Syarat Kontrak dalam Perdagangan Secara Elektronik}

Terdapat berbagai situs yang menawarkan perdagangan barang secara elektronik. Situs tersebut dikembangkan di Indonesia dengan berbagai model penawaran barang dan syaratsyarat kontrak berbeda-beda yang secara normatif dimungkinan oleh peraturan perUndangundangan, khususnya Kitab Undang-undang Hukum Perdata (selanjutnya disingkat KUHPerdata). Pasal 1320 KUHPerdata menentukan bahwa sahnya suatu perjanjian diperlukan 4 (empat) syarat, yaitu : (1) sepakat mereka yang mengikat dirinya, (2) cakap untuk membuat suatu perjanjian, (3) mengenai suatu hal tertentu, dan (4) suatu sebab yang halal. Dua syarat pertama disebut syarat subjektif karena berhubungan dengan orang (subjek) atau pihak yang mengadakan kontrak, adapun syarat ketiga dan keempat menandai 
sebagai syarat objektif karena berhubungan dengan objek dari hubungan hukum dan perbuatan hukum para pihak.

Dalam konteks tersebut, dapat terjadi secara teknis-elektronik suatu kontrak dianggap valid, namun secara substansial tidak mencerminkan keadilan karena terjadi perlindungan kepentingan yang lebih pada salah satu pihak dan kurang pada pihak lain. Namun informasi elektronik dan/atau dokumen elektronik yang berupa kontrak itu dapat diakses, ditampilkan, dijamin keutuhanya, dan dapat dipertanggungjawabkan, sehingga menerangkan suatu keadaan. Permasalahanya terletak pada tidak dapat dipastikan bahwa para pihak, khususnya konsumen memahami isi atau maksud kontrak tersebut. Padahal secara substansial benarbenar dipahami atau tidak, dapat membawa pada validitas kontrak yang disepakatinya melalui model clickwrap. Kenyataannya secara elektronik, apapun keadaan pembeli atau konsumen dalam hubungan dengan isi kontrak, bentuk elektronik dari kontrak dan informasi mengenai syarat kontrak tersebut memeroleh pengakuan validitas (keabsahan)-nya (Gunawan, 1999).

Perdagangan secara elektronik (electronic commerce atau e-commerce) meliputi transaksi perusahaan-ke-perusahaan (business-to-business [B2B]) dan perusahaan-kekonsumen (business-to-consumer [B2C]). B2B menggambarkan perdagangan antar perusahaan atau entitas yang berbeda. Transaksi ini dapat dipenuhi melalui kinerja terhadap kinerja, seperti ketika satu pihak menyediakan data statistik ditukarkan dengan hasil penelitian pasar. Umumnya B2B memberikan barang atau jasa kepada perusahaan lainnya. Adapun B2C melibatkan penjualan barang atau jasa pada pelanggan (konsumen) individual untuk digunakan sendiri. Dalam transaksi B2C, salah satu pihak bertindak sebagai seorang pelanggan (konsumen). Sinonim untuk perdagangan secara elektronik B2C, yaitu "penjualan eceran secara elektronik" (electronic retailing). B2C dengan demikian merupakan bentuk transaksi elektronik secara eceran antara pengusaha dan konsumen, yang menunjukkan kuantitas dan nilai transaksi yang kecil (Gillies, 2008).

Perdagangan secara elektronik yang dilakukan oleh toko online di Indonesia umumnya merupakan transaksi B2C dan C2C, seperti Lazada, Zalora, OLX, dan Bukalapak, meskipun perkembangan perdagangan secara elektronik justru dimulai atau awalnya terbatas pada B2B. Pergeseran transaksi B2C dengan menggunakan WWW (World Wide Web) baru diinisiasi sekitar awal tahun 1990-an, perdagangan secara elektronik yang berbasis 
konsumen itu mulai berkembang (Todd, 2007). Dengan demikian, fenomena perdagangan secara elektronik yang kita kenal saat ini, setidaknya B2C, baru sekitar 20 tahun yang lalu.

Dalam rentang waktu yang relatif pendek perkembangan toko online di Indonesia khususnya telah mengubah perilaku perdagangan di Indonesia, khususnya antara perusahaan-ke-konsumen (B2C). Hal ini telah cukup melahirkan isu-isu perdagangan secara elektronik yang menantang ketentuan-ketentuan hukum kontrak berdasarkan KUHPerdata untuk mampu menjangkau. Pada perkembangannya menuntun lahirnya UU ITE pada tahun 2008, yang sebagiannya mengatur beberapa aspek perdagangan secara elektronik.

Dalam B2C maupun $\mathrm{C} 2 \mathrm{C}$, konsumen atau pembeli sangat variatif pengetahuannya mengenai kontrak, mulai yang tidak paham sampai sangat paham. Berbeda halnya dengan B2B, yang sudah terbiasa melakukan jual-beli dalam skala besar di samping mereka masingmasing sebagai pelaku usaha yang setidak-tidaknya terbiasa dengan kontrak bisnis. Dalam B2C maupun $\mathrm{C} 2 \mathrm{C}$ tidak jarang konsumennya masih belum dewasa, dan hal ini tidak dapat dideteksi oleh penjual yang bertransaksi dengannya.

Menentukan saat kontrak dibuat (ditutup) dalam transaksi elektronik bukan persoalan sederhana sebagaimana kontrak secara tradisional atau konvensional. Hal tersebut meniscayakan pengujian waktu pengiriman dan penerimaan komunikasi elektronik dan aturan-aturan yang berhubungan dengan penawaran serta penerimaan, maupun kesalahan dalam komunikasi-komunikasi elektronik.

Setelah kesepakatan dicapai atau terjadi pertemuan kehendak di antara para pihak yang terlibat dalam transaksi elektronik, baru dibuatlah kontrak yang bersifat formal. Dalam hukum Inggris (English law), pertemuan kehendak itu diformalisasi ke dalam ide mengenai penawaran oleh salah satu pihak yang berkontrak dan diterima oleh pihak lainnya. Menurut Edmon Makarim, hampir sama dengan kontrak jual beli pada umumnya, kontrak jual beli online juga terdiri dari penawaran dan penerimaan. Suatu kesepakatan selalu diawali dengan adanya penawaran oleh salah satu pihak dan penerimaan oleh pihak lain. (Barkatullah, 2009) Meskipun demikian, soal penawaran dan penerimaan dalam transaksi perdagangan secara elektronik lebih kompleks dan rumit daripada transaksi konvensional.

Ketika suatu penawaran diterima, maka diambil suatu langkah yang tidak dapat dibatalkan, dan para pihak secara kontraktual terikat. Hal ini berbeda dengan tahap negosiasi yang dilakukan sebelumnya, yang memungkinkan tiap-tiap pihak dapat menarik diri dari negosiasi tanpa konsekuensi hukum. Hal tersebut kemudian berarti baik pihak yang 
menawarkan (offeror) dan yang menerima telah membuat komitmen, penerimaan pertimbangan-pertimbangan yang jelas, di samping penawaran juga disebabkan apabila pihak lain menerima, maka hal itu akan menjadikan kontrak mengikat. Penerimaan niscaya selalu menjadi tindakan final. Apabila masih ada lagi yang perlu dilakukan, berarti belum ada penerimaan (Todd, 2005).

Informasi syarat kontrak dalam literatur dan praktik di berbagai negara sering dituangkan dengan menggunakan istilah "the terms and conditions" - dalam bahasa Indonesia sering diterjemahkan dengan istilah "syarat dan ketentuan". Frasa tersebut merupakan batasan hak (rights) dan tanggung jawab atau tanggung gugat (liabilities) para pihak dalam kontrak. Hal tersebut sangat penting karena menentukan syarat dan ketentuan kontrak dagang yang secara jelas merefleksikan syarat dan ketentuan yang telah dinegosiasi dan disepakati oleh para pihak. Sebuah kontrak yang dirancang secara buruk akan meningkatkan risiko kesalahpahaman dan sengketa dagang yang dapat menimbulkan penundaan pembayaran atau kinerja, kompensasi, dan jaminan sengketa.

Semua toko online Indonesia belum mengadakan fitur semacam "Buyer Pretection" (perlindungan pembeli), sehinga hanya mengandalkan UU Perlindungan Konsumen dan UU ITE serta klausula-klausula sebagaimana termuat dalam informasi syarat kontrak yang secara tidak eksplisit sebagai bentuk perlindungan konsumen toko online kepada pembeli. Hal ini tentu merupakan faktor limitasi keefektivan perlindungan konsumen. Artinya, tujuan perlindungan konsumen derajat atau tingkatan pencapaiannya secara praktis tidak optimal. Sikap atau langkah-langkah progresif dari toko online dengan sendirinya tidak mudah sebab berkaitan dengan kepentingan yang bersaing di antara pelaku usaha atau toko online dan pembeli atau konsumen.

\section{Kelemahan Informasi SyaratKontrakdalamPerdaganganSecaraElektronik}

Informasi syarat kontrak ini menjadi pintu masuk bagi konsumen untuk melanjutkan keinginannya dalam memenuhi kebutuhan atas barang atau jasa. Dengan informasi tersebut, setidak-tidaknya konsumen dapat mengetahui perlindungan atas posisinya sebagai faktor kalkulasi untuk bertransaksi atau tidak. Apabila informasi syarat kontrak menunjukkan posisi lemah atau tidak adil pada konsumen, secara rasional konsumen seharusnya tidak mengambil risiko untuk melakukan transaksi online tersebut, demikian pula sebaliknya. Meskipun demikian, subjektivitas penilaian atas besar-kecilnya risiko pada posisi lebih 
lemah atau syarat yang tidak adil juga memengaruhi kehendak konsumen untuk melanjutkan transaksi atau meninggalkan transaksi.

Konsumen dengan demikian tidak selalu dapat menilai lemah, kuat, atau keseimbangan posisinya dalam hubungan dengan penjual atau pengusaha. Hal ini berarti antara kelemahan informasi syarat kontrak yang mengakibatkan ketidakseimbangan posisi antara pelaku bisnis dan konsumen ataupun ketidakamanan bagi konsumen, tidak berbanding lurus dengan sikap konsumen untuk memilih tetap bertransaksi atau membatalkan transaksi dengan meninggalkan toko online dan mencari toko online lain yang dianggap lebih adil dan melindungi kepentingan konsumen apabila terjadi wanprestasi atau perbuatan melawan hukum.

Berdasarkan hal tersebut, syarat dan ketentuan suatu situs web menawarkan barang atau jasa untuk dijual membutuhkan pengaturan Undang-undang perlindungan konsumen. Hal ini mencakup lebih dari sekedar syarat penjualan, tetapi juga mempengaruhi, misalnya, bagaimana barang atau jasa yang dipasarkan atau diiklankan, sarana akses konsumen untuk menawarkan dibuat dan hak-hak konsumen sebelum dan setelah penjualan ditutup.

Beberapa kelemahan informasi syarat kontrak yang potensial menimbulkan posisi lemah bagi konsumen dapat dikemukakan sebagai berikut :

\section{a. Informasi Syarat Kontrak Mengarahkan pada Kontrak Baku yang Tidak Seimbang}

Permasalahan kontrak baku dalam informasi syarat kontrak bukan terletak pada pembentukan klausula-klausula yang bersifat sepihak oleh toko online, sementara pihak lain (konsumen) hanya menyepakati atau meninggalkan toko online, namun pada keseimbangan perlindungan kepentingan pihak-pihak yang bertransaksi. Ketidakseimbangan perlindungan kepentingan potensial merugikan salah satu pihak, khususnya konsumen. Dalam hubungan dengan keadilan, ketidakseimbangan perlindungan kepentingan dalam kontrak baku itu menjelaskan ketidakadilan.

Kenyataan menunjukkan bahwa tidak ada toko online yang menawarkan dalam informasi syarat kontrak mengenai kemungkinan konsumen melakukan negosiasi atas klausula-klausula kontrak perdagangan. Informasi syarat kontrak menunjukkan "pendekatan berdasarkan kekuasaan pada kontrak" (power-based approaches to contact). Kekuasaan dimaksud adalah pelaku usaha atau toko online yang membuat informasi itu.

\section{b. Informasi Syarat Kontrak SulitDiakses}


Informasi syarat kontrak yang sulit diakses, maka terhadap perubahan syarat dan ketentuan yang dilakukan oleh toko online dengan demikian juga sulit diketahui. Informasi, pemberitahuan atau publikasi adanya perubahan syarat dan ketentuan masih problematis bagi konsumen karena tidak disebutkan secara spesifik. Konten perubahan niscaya diakses pada awal seseorang mendaftar sebagai pengguna dan sebagaimana dikatakan di atas, setelah pengguna terdaftar, maka perubahan dianggap diketahui dan disetujui oleh pengguna kendati pengguna tidak mengakses Syarat dan Ketentuan yang berubah tersebut pada setiap waktu memasuki toko online tersebut.

\section{c. Informasi syarat kontrak tidak lengkap dan jelas}

Informasi syarat kontrak merupakan bagian dari keamanan perdagangan secara elektronik. Artinya, semakin minimal informasi syarat kontrak, maka semakin tidak aman transaksi elektronik yang dibuat oleh para pihak. Sebaliknya, semakin lengkap informasi syarat kontrak, maka perdagangan secara elektronik tersebut lebih aman. Informasi syarat kontrak yang lengkap sangat penting, terutama bagi lingkungan konsumen yang belum terbiasa berbelanja secara online. Informasi syarat kontrak yang lengkap setidak-tidaknya memberi pengetahuan pada konsumen atas kesepakatan-kesepakatan yang dibuat dengan pelaku usaha maupun penyelenggara sistem layanan perdagangan secara elektronik.

Kesalahan penerimaan informasi disebabkan informasi syarat kontrak cacat, baik karena pelaku usaha tidak jujur atau informasi itu tidak lengkap merupakan faktor yang niscaya menjadikan kontrak tidak sah (valid). Ketiadaan ketentuan mengenai hal ini sangat merugikan konsumen atau setidak-tidaknya kepentingan konsumen tidak terlindungi.

\section{Simpulan}

Informasi syarat kontrak dalam perdagangan secara elektronik masih menempatkan konsumen pada posisi yang lemah meskipun telah terdapat UU ITE, sehingga keadilan masih problematis bagi konsumen. Ketentuan-ketentuan dalam UU ITE maupun UU Perlindungan Konsumen masih sangat simplistis (sederhana) untuk mengatakan telah adanya jaminan keadilan dalam perdagangan secara elektronik khususnya bagi konsumen. Dengan ungkapan lain, standar perlindungan konsumen dalam praktik perdagangan secara elektronik masih rendah baik karena tidak ada persyaratan keadilan dalam syarat kontrak itu sendiri maupun 
kontrak yang akan disepakati bersifat standar atau baku. Bahkan UU ITE belum mengatur mengenai validitas kontrak sebagai bagian dari informasi syarat kontrak. Sampai pada batas ini keadilan masih belum sepenuhnya terdistribusi pada konsumen dalam perdagangan secara elektronik.

Kelemahan perlindungan konsumen yang menunjukkan ketidakseimbangan posisi antara pelaku usaha dan konsumen di antaranya, yaitu UU ITE maupun UU Perlindungan Konsumen dan informasi syarat kontrak memungkinkan bahkan mengarahkan pada kontrak baku yang tidak seimbang; informasi syarat kontrak sulit diakses; serta informasi syarat kontrak tidak lengkap dan jelas.

\section{DAFTAR PUSTAKA}

\section{A. BUKU-BUKU}

Apeldoorn, L. J. Van. (1996). Pengantar Ilmu Hukum. Cetakan kedua puluh enam. Jakarta: Pradnya Paramita.

Badrulzaman, Mariam Darus. (1986). Perlindungan Terhadap Konsumen Dilihat Dari Sudut Perjanjian Baku (Standar),dalam BPHN, Simposium Aspek - Aspek Hukum Perlindungan Konsumen. Bandung: Binacipta.

Barkatullah, Abdul Halim. (2009). Perlindungan Hukum bagi Konsumen dalam Transaksi E-Commerce Lintas Negara di Indonesia. Yogyakarta: FH UII Press.

Blythe, Stephen Errol. (2012). The E-Commerce Law Trilogy: Volime 2, An E-Commerce Law for the World: The Model Electronic Transaction Act. USA: Xlibris Corporation.

Gillies, Lorna E. (2008). Electronic Commerce and International Private Law, A Study of Electronic Consumer Contracts. Hampshire: Ashgate Publishing Limited.

Gunawan, Johanes. (1999). Hukum Perlindungan Konsumen. Bandung: Universitas Katolik Parahyangan.

Shidarta. (2000). Hukum Perlindungan Konsumen Indonesia. Jakarta: Grasindo.

Todd, Paul. (2005). E-Commerce Law. Oregon: Cavendish Publishing Limited. (2007). E-Commerce Law, London, Sydney, Portland. Oregon: Cavendish Publishing Limited.

Wignjosoebroto, Soetandyo. (2002). Hukum, Paradigma, Metode dan Dinamika Masalahnya. Jakarta: Elsam dan Huma. 


\section{B. ARTIKEL JURNAL}

Faiz, Pan Mohamad. (2009). “Teori Keadilan John Rawls (John Rawls' Theory of Justice).” SSRN Electronic Journal. https://doi.org/10.2139/ssrn.2847573.

Gunawan, Hartini. (2015). “Tanggung Jawab Dan Perlindungan Hukum Para Pihak Dalam Transaksi Bisnis Elektronik.” Legal Opinion 3 (1).

Putra, Setia. (2014). "Perlindungan Hukum Terhadap Konsumen Dalam Transaksi Jualbeli Melalui E-commerce.” Jurnal Ilmu Hukum Riau 4 (2).

Setyawati, Desy Ary. (2017). "Perlindungan Bagi Hak Konsumen dan Tanggung Jawab Pelaku Usaha dalam Perjanjian Transaksi Elektronik.” Syiah Kuala Law Journal 1 (3): $46-64$.

\section{UNDANG-UNDANG DAN PERATURAN}

Kitab Undang-undang Hukum Perdata.

Undang-undang Nomor 8 Tahun 1999 tentang Perlindungan Konsumen.

Undang-undang Nomor 11 Tahun 2008 tentang Informasi dan Transaksi Elektronik.

Undang-undang Nomor 19 Tahun 2016 tentang Perubahan atas Undang-undang Nomor 11 Tahun 2016 tentang Informasi dan Transaksi Elektronik.

Undang-undang Perlindungan Konsumen Pasal 7 huruf b. 